\title{
KONSEP KESEJAHTERAAN MASYARAKAT DALAM PERSPEKTIF AL-QUR'AN
}

\author{
Dahliana Sukmasari \\ Fakultas Ushuluddin dan Studi Agama, UIN Sulthan Thaha Saifuddin, Jambi, Indonesia, \\ dahlianasukmasari@gmail.com
}

\begin{abstract}
Abstrak:
Penelitian ini dilatar belakangi oleh realitas yang memprihatinkan dan memerlukan perhahian yaitu cara pandang masyarakat terhadap pencapaian kesejahteraan yang terlalu materialistik. Hal ini mendorong penulis untuk menganalisisa kembali konsep kesejahteraan masyarakat yang termuat dalam al-Qur'an yang dijabarkan oleh para mufassirin melalui tulisan-tulisannya. khususnya pada kitab tafsir tahlili corak adabul ijtima'I karya M. Quraish Shihab, Ahmad Musthafa Al-Maraghi dan Buya Hamka. Pendekatan penelitian yang penulis gunakan adalah (library research) dalam teknis deskriptif kualitatif eksploratif dengan menekankan pada sumber tertulis terutama karya tafsir M. Quraish Shihab, Ahmad Musthafa Al-Maraghi dan Buya Hamka (Tafsir Al-Mishbah, Tafsir Al-Maraghi dan Tafsir Al-Azhar). dalam pengumpulan data peneliti menggunakan teknik penelusuran yakni menelusuri kata kesejahteraan masyarakat yang terdapat dalam buku-buku perpustakaan, jurnaljurnal maupun web-site. Hasilnya penulis menemukan bahwa hakikat kesejahteraan itu dapat diperoleh apabila masyarakat terbebas dari jeratan kekufuran, kemiskinan, kebodohan dan rasa takut. dan hal ini didapatkan apabila masyarakat memperkukuh keimanan dan tidak mencampurkannya dengan segala bentuk kezhaliman lalu kemudian direalisasikan melalui amal saleh atau amal kebajikan.. Akhirnya penulis merekomendasikan kepada umat Islam untuk dapat menambah keimanan dengan cara lebih mengenal Allah sehingga dapat menarik perhatian-Nya untuk memberikan anugerah kesejahteran.
\end{abstract}

Kata Kunci: Kesejahteraan, Masyarakat, Al-Qur'an

\begin{abstract}
:
This research is motivated by a reality that is alarming and requires attention, namely the way of society's view of achieving welfare that is too materialistic. This prompted the author to re-analyze the concept of public welfare contained in the Qur'an which was elaborated by the mufassirin through his writings. especially in the tahlili interpretation book, the form of adabul ijtima'i by M. Quraish Shihab, Ahmad Musthafa Al-Maraghi, and Buya Hamka. The research approach that I use is (library research) in explorative qualitative descriptive techniques by emphasizing written sources, especially the works of M. Quraish Shihab, Ahmad Musthafa AlMaraghi and Buya Hamka (Tafsir Al-Mishbah, Tafsir Al-Maraghi and Tafsir AlAzhar). in data collection, researchers used a search technique that is searching for the word community welfare contained in library books, journals and websites. The results of the authors find that the nature of welfare can be obtained if the community is free from the bondage of kufr, poverty, ignorance and fear. and this is
\end{abstract}




\section{AT-TIBYAN}

Journal Of Qur'an and Hadis Studies

Vol. 3 No. 1 (Juni 2020)

obtained if the community strengthens the faith and does not mix it with all forms of tyrannical faith and then it is realized through good deeds or good deeds. Finally, the author recommends Muslims to be able to increase their faith by getting to know God so that they can draw attention to give gifts prosperity.

Keywords: Welfare, Society, Al-Qur'an

\section{PENDAHULUAN}

Kehidupan yang didambakan oleh semua manusia di dunia ini adalah kesejahteraan baik tinggal di kota maupun yang di desa, Sejahtera lahir dan bathin. Kesejahteraan adalah sebuah tata kehidupan sosial, material maupun spiritual yang diikuti dengan rasa keselamatan, kesusilaan dan ketentraman diri, setiap warga negara dapat melakukan usaha pemenuhan kebutuhan jasmani, rohani dan sosial yang sebaik-baiknya bagi diri sendiri, rumah tangga, serta masyarakat dengan menjunjung tinggi hak-hak asasi. Kesejahteraan menurut Badan Pusat Statistik (2007) adalah suatu kondisi dimana seluruh kebutuhan jasmani dan rohani dari rumah tangga tersebut dapat dipenuhi sesuai dengan tingkat hidup.

Manusia adalah makhluk yang hidup dalam keberadaan makhluk lain, dan hidup berdampingan dengan sesamanya. Ia selama hidup di dunia sejak lahir sampai mati, memang tidak bisa lepas dari manusia lainnya. Karena itu manusia adalah makhluk individu sekaligus makhluk sosial (yang bermasyarakat)(Kaelany, 2000, hlm. 157) Hubungan antar manusia di dalam al Qur'an adalah adanya penciptaan Allah yang berbeda-beda dalam kehidupan manusia seperti laki-laki dan perempuan, suku-suku yang banyak, berbangsa-bangsa, bahasa yang berbeda-beda, serta warna kulit yang tidak sama dan berbagai keanekaragaman lainnya agar manusia tersebut saling mengenal satu sama lainnya dan bukan untuk menjelekkan perbedaan tersebut. Namun, bagaimana mereka bisa bersatu dengan segala perbedaan tersebut untuk menciptakan sebuah kehidupan yang harmonis yang penuh dengan kedamaian, karena manusia adalah makhluk sosial yang saling membutuhkan satu sama lainnya dan mereka tidak akan bisa hidup dengan individu mereka sendiri.(Mustaniruddin, 2019, hlm. 47) Sebagaimana firman Allah dalam QS. al-Hujurat: 13.

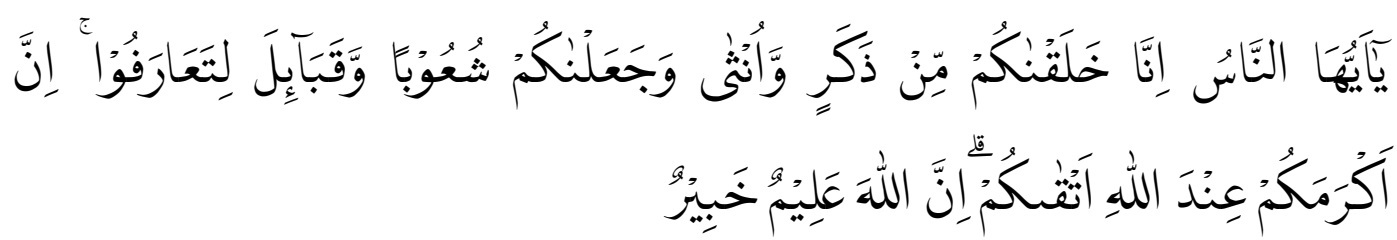

"Hai manusia, Sesungguhnya Kami menciptakan kamu dari seorang laki-laki dan seorang perempuan dan menjadikan kamu berbangsa-bangsa dan 
bersuku-suku supaya kamu saling kenal-mengenal. Sesungguhnya orang yang paling mulia diantara kamu disisi Allah ialah orang yang paling taqwa diantara kamu. Sesungguhnya Allah Maha mengetahui lagi Maha Mengenal." (QS. Al-Hujurāt 49; 13)(Kementerian Agama RI, 2015, hlm. 517)

Meskipun manusia diciptakan dalam beribu-ribu tabiat dan selera dalam keindividuan dan pribadi, namun ia difitrahkan untuk hidup bermasyarakat. Adalah di luar jangkauan kemampuan manusia untuk hidup sendiri-sendiri. Para peneliti menemukan, bahwa siksaan yang paling mencekam bagi manusia adalah terkurungnya ia dalam penjara kesendirian. Demikian itu karena setiap individu pada dasarnya sangat banyak tergantung pada nilai-nilai kemanusiaan dan keberadaanya dalam kelompok.(Kaelany, 2000, hlm. 157)

Selain itu manusia juga membutuhkan lembaga atau institusi yang memfasilitasi, melindungi dan mengatur berbagai norma-norma dan aturanaturan yang memudahkan bagi mereka untuk memenuhi kebutuhannya, dalam istilah modern lembaga tersebut dikenal dengan "Pemerintahan" para pencetus kemerdekaan bangsa Indonesia telah merumuskan kesejahteraan sebagai tujuan bangsa dalam batang tubuh UUD 1945 dan telah menjabarkannya dalam bab perekonomian nasional dan kesejahteraan sosial dalam pasal 33 UUD 1945 dengan menegaskan bahwa fakir miskin dan anakanak terlantar dipelihara oleh negara, sayangnya harapan dan cita-cita tersebut masih jauh dari kenyataan.(Sodiq, 2015, hlm. 382)

Kesejahteraan di Indonesia dilaksanakan dengan filosofi, kesejahteraan adalah hak bagi setiap warga negara atau welfare of all. Atas dasar filosofi tersebut, maka fakir miskin sebagai warga negara Indonesia berhak atas kesejahteraan sebagaimana warga negara Indonesia pada umumnya. Mereka memiliki hak untuk hidup sejahtera, yang ditandai dengan terpenuhinya kebutuhan material, spiritual, dan sosial untuk dapat hidup secara layak dan mampu mengembangkan diri, serta mampu melaksanakan fungsi sosialnya.(Amelia, 2018, hlm. 4)

Kesejahteraan hidup seseorang pada realitanya memiliki banyak indikator yang dapat diukur. Pengukuran tingkat kesejahteraan seseorang juga sering mengalami perubahan dari waktu ke waktu. Pada tahun 1980-an terjadi perubahan dimana kesejahteraan diukur dari income, tenaga kerja dan hak-hak sipil. Pada tahun 1990-an terjadi perubahan lagi, Mahbub UlHaq merumuskan ukuran kesejahteraan dengan Human Development Index (HDI). Dengan HDI, kesejahteraan tidak lagi ditekankan pada aspek ekonomi saja, tetapi juga pada aspek kualitas sosial individu. HDI merupakan 
gabungan dari tiga komponen, yaitu indeks harapan hidup, indeks pendidikan, dan indeks pendapatan per kapita.(Sardar \& H.r, 2016, hlm. 394)

Di antara aspek yang sering digunakan sebagai indikator ukuran kesejahteraan adalah pendapatan, populasi, kesehatan, pendidikan, pekerjaan, konsumsi, perumahan, dan sosial budaya. Jika kita menggunakan indikator tersebut, maka akan timbul pertanyaan apakah pemenuhan indikator tersebut menjamin seseorang mendapatkan kesejahteraan?. Apabila iya, mengapa beberapa orang sudah memiliki rumah mewah, kendaraan, deposito dan berbagai bentuk properti lainnya harus merasa gelisah, takut, bahkan ada yang mengakhiri hidupnya dengan bunuh diri. Berdasarkan fakta di atas, tampaknya ada yang kurang dalam mengukur kesejahteraan masyarakat.

Dalam ekonomi Islam, kebahagiaan diberikan oleh Allah kepada siapapun (pria dan wanita) yang ingin melakukan perbuatan baik bersama dengan iman kepada Allah. Seperti yang disebutkan oleh Allah dalam Surat An-Nahl 97 sedangkan tiga indikator untuk mengukur kesejahteraan dan kebahagiaan dalam Islam adalah tauhid, konsumsi, dan hilangnya segala bentuk ketakutan dan kecemasan. Hal itu seperti yang disebutkan Konsep Kesejahteraan dalam Islam Allah dalam Q.S Quraisy 3-4.10.(Hilmi, 2018, hlm. 8)

Dari perbedaan pemahaman tolak ukur kesejahteraan tersebut, baik itu dari kerangka berpikir material, spiritual dan pelaku ekonomi konvensional. Dalam Islam memiliki ukuran kesejahteraan yang berbeda. Ini bisa dipahami dari ayat al-Qur'an yang menjelaskan tentang kesejahteraan salah satunya ialah QS Al-An'am 82,

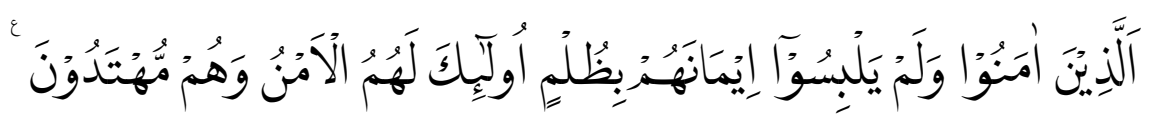

"Orang-orang yang beriman dan tidak mencampuradukkan iman mereka dengan kezaliman (syirik), mereka Itulah yang mendapat keamanan dan mereka itu adalah orang-orang yang mendapat petunjuk" (QS. Al-An'am 6: 82)(Kementerian Agama RI, 2015, hlm. 138)

Al-Qur`an menggunakan beberapa istilah yang berarti kesejahteraan masyarakat. Di antara istilah-istilah itu ada yang cakupan maknanya sudah jelas dan lugas dan ada yang masih membutuhkan interpretasi. Secara kategoris istilah tafsir dapat dibedakan menjadi dua yaitu: Pertama, tafsir sebagai produk, ia merupakan hasil dialektika seorang mufassir dengan teks dan konteks baik secara lengkap 30 juz, maupun yang hanya sebagian ayat alQur'an. Kedua, tafsir sebagai proses, ia merupakan aktifitas berpikir untuk menafsirkan objek (dalam hal ini teks al-Qur'an dan realitas). Sebagai proses, 
maka ia bersifat dinamis untuk selalu 'menghidupkan' teks secara terusmenerus dan tidak pernah mengenal titik henti. Hal ini sesungguhnya merupakan konsekuwensi logis dari keinginan seorang mufassir untuk mendialogkan teks al-Qur'an yang statis, dengan konteks yang selalu dinamis. Tafsir sesungguhnya bersifat dinamis dan merupakan proses yang tak pernah mengenal titik henti, terbukti secara historis kaum muslimin telah melakukan kajian tafsir, sejak Nabi Muhammad SAW, para sahabat, tabi'in dan bahkan hingga sekarang ini.(Jamil, 2011, hlm. 1)

Sketsa penafsiran yang digambarkan Abdul Mustaqim, Ia mengklasifikasi perkembangan metodologi tafsir menjadi tiga era, tafsir era formatif dengan nalar quasi-kritis, tafsir era afirmatif dengan nalar ideologis dan tafsir era reformatif dengan nalar kritis.(Mustaqim, 2009, hlm. 31)

Pertama, era formatif yang berbasis pada nalar quasi-kritis. Artinya, hasil penafsiran masih diterima begitu saja sebagai kebenaran tanpa ada kritisisme di dalamnya. Pergeseran episteme berikutnya adalah di era afirmatif penafsiran di era ini lebih didominasi oleh kepentingankepentingan idiologi tertentu, sehingga al-Qur'an seringkali diperlakukan hanya sebagai legitimasi idiologis, teologis atau madzab tertentu. Posisi alQur'an di sini cenderung sebagai obyek, sedangkan realitas dan mufassirnya sebagai subyek. Akibatnya sering terjadi pemaksaan gagasan non qur'ani dalam penafsiran al-Qur'an. Era reformatif ditandai dengan cara berpikir kritis dan transformatif. Artinya, hasil penafsiran yang ada sudah mulai dikritisi dengan nalar ilmiah, dan tafsir dibangun untuk kepentingan transformasi umat. Di era reformatif yang berbasis pada nalar kritis, posisi al-Qur'an, realitas dan mufassir menjadi objek subjek sekaligus.(Jamil, 2011, hlm. 470-479)

Akibat adanya pergeseran epistemolog tafsir tersebut menjadikan kata (ظلم) zulum pada ayat di atas tidak lagi ditafsirkan dengan pendekatan teologi saja yaitu "syirik" yang berarti kekal di neraka. Tetapi, dengan berkembangnya periode penafsiran dan konsekuensi logis dari diktum yang dianut oleh umat Islam bahwa Al-Qur'an itu shalihun li kulli zaman wa makan(Mustaqim, 2003, hlm. xi) kata (ظلم) zulum mengalami pengembangan penafsiran yaitu dengan munculnya pendekatan adabul ijtima'I/sosial menafsirkan kata (ظ) dzulum dengan perbuatan dosa yang dapat merugikan orang lain. Tidak hanya itu Dalam sebuah jurnal bapak Dr. D.I. Ansusa Putra di jelaskan bahwa dalam kisah Musa kata zalim disamakan juga dengan kata ketidak tahuan (jahiliyyah) bahkan tirani.(Romziana, 2014, hlm. 113)

Pada ayat di atas kata al-amnu adalah konotasi dari kata sejahtera, dalam kamus lengkap al-Fikr dimuat bahwa makna kata sejahtera dalam 
bahasa Arab adalah al-amnu atau as-salämu.(Sunarto, 2002, hlm. 176) Juga dalam kamus kontomporer Arab Indonesia amnu, thuma'ninah dan salām, berarti ketentraman, ketenangan, kedamaian.(Muhdlor, 1996, hlm. 225)

Jika kata zulum pada ayat ini dipahami dalam arti syirik, maka keamanan yang dimaksud adalah kemanan dari siksa duniawi yang memunahkan orang-orang durhaka dan dari siksa akhirat yaitu kekekalan di neraka. Jika kata zulum dipahami dalam segala macam dosa, maka tentu saja keamanan yang dimaksud adalah kesejahteraan hidup duniawi dan keberkahannya serta kabahagiaan akhirat dengan peringkat sangat tinggi di akhirat nanti.(Shihab, 2012, hlm. 173) Jika mereka tidak mencampur iman dengan kezaliman secara mutlak, baik itu syirik dan kemaksiatan, maka mereka mendapatkan rasa aman dan hidayah yang sempurna.(al-Sa'di, 2001, hlm. 484)

Ayat ini menjelaskan rasa aman sentosa dapat terwujud ketika seseorang benar-benar beriman dan bertaqwa lalu menjaga diri dari segala bentuk kezaliman (yang sudah dijelaskan maksudnya diatas). Terpenuhinya kebutuhan ini merupakan unsur pertama dan utama dari kesejahteraan. Oleh karena itu, masyarakat diharapkan dapat meningkatkan keimanan dan ketakwaan. Masyarakat sejahtera atas dasar iman dan taqwa, menjadi tujuan akhir dalam kehidupan manusia di dunia ini.

Sebagai orang Islam, adanya pandangan yang berbeda dengan orang-orang yang berpegang pada ekonomi konvensional dalam hal kesejahteraan adalah suatu hal yang lazim, karena itu sangatlah menarik untuk membahas dan mengkaji konsep kesejahteraan dalam Islam, Berkanaan dengan hal tersebut, tulisan ini akan mencoba menjelaskan tentang kesejahteraan hidup di dunia melalui pendekatan studi kitab tafsir tahlili bercorak adabul ijtima'i, dengan judul “Konsep Kesejahteraan Masyarakat Dalam Perspektif Al-Qur'an: Studi Kitab Tafsir Tahlili Corak Adabul Ijtima'i'.

\section{PEMBAHASAN}

\section{Pengertian Kesejahteraan Masyarakat}

Sejahtera, menurut Kamus Besar Bahasa Indonesia, merujuk pada situasi yang aman sentosa, dan makmur. Aman berarti terbebas dari bahaya dan gangguan. Hidup yang aman menandakan suatu kehidupan yang terbebas dari segala kesukaran dan bencana. Sehingga, hidup yang sentosa adalah hidup dalam suasana aman, damai dan tidak ada kekacauan. Dalam arti yang lebih luas kesejahteraan adalah terbebasnya seseorang dari jeratan kemiskinan, kebodohan dan rasa takut sehingga dia memperoleh kehidupan 
yang aman dan tenteram secara lahiriah maupun batiniah.(Sodiq, 2015, hlm. 384) Dalam KBBI masyarakat adalah sejumlah manusia yang terikat oleh suatu kebudayaan yang mereka anggap sama.(Sugono, 2003, hlm. 405) Menurut Charles Horton masyarakat adalah sesuatu yang menyeluruh yang mencakup berbagai bagian yang berkaitan secara sistematisfungsional.(Soekanto, 1993, hlm. XIII)

Kesejahteraan masyarakat adalah kondisi terpenuhinya kebutuhan dasar yang tercermin dari rumah yang layak, tercukupinya kebutuhan sandang dan pangan, biaya pendidikan dan kesehatan yang murah dan berkualitas atau kondisi dimana setiap individu mampu memaksimalkan utilitasnya pada tingkat batas anggaran tertentu dan kondisi dimana tercukupinya kebutuhan jasmani dan rohani.(Dura, 2016, hlm. 26)

\section{Kesejahteraan Masyarakat Berdasarkan Penafsiran Para Mufassir terhadap QS Al-An'am 82, Al-A'raf 96 dan An-Nūr 55.}

"Orang-orang yang beriman dan tidak mencampuradukkan iman mereka dengan kezaliman (syirik), mereka Itulah yang mendapat keamanan dan mereka itu adalah orang-orang yang mendapat petunjuk." (QS. Al-An'ām 6: 82).(Kementerian Agama RI, 2015, hlm. 138)

Al-Maraghi menjelaskan bahwa keamanan adalah keamanan dari azab Allah yang menimpa kepada orang yang beriman dan ibadahnya diridhai oleh Allah. Yakni: sesungguhnya orang-orang yang beriman kepada Allah Ta`ala dan tidak mencampurkan keimanannya dengan lezaliman yang besar, yaitu mempersekutukan-Nya, hanya bagi merekalah tanpa yang lainnya keamanan kekekalan di negeri azab (neraka). Sedang di balik itu mereka berada antara harap dan cemas.(Al-Maraghi, 1993, hlm. 306) Ringkasnya untuk meraih kesejahteraan maka seseorang harus tetap menjaga keimanannnya dan tidak mencampurkannya dengan kesyirikan.

Sedangkan Quraish Shihab dalam tafsirnya menjelaskan jika kata zhulum pada ayat ini dipahami dalam arti syirik, maka keamanan yang dimaksud adalah kemanan dari siksa duniawi yang memunahkan orangorang durhaka dan dari siksa ukhrawi yaitu kekelan di neraka. Jika kata zhulum dipahami dalam segala macam dosa, maka tentu saja keamanan yang dimaksud adalah kesejahteraan hidup duniawi dan keberkahannya serta kabahagiaan ukhrawi dengan peringkat sangat tinggi di akhirat nanti. (Shihab, 2012, hlm. 173)

Buya Hamka dalam tafsirnya tidak memaknai dzulum dengan syirik atau dengan segala macam dosa beliau mengambil arti asal dari kalimat zhulum, yaitu kegelapan yang kemudian makna dari akibat kegelapan itu 


\section{AT-TIBYAN}

Journal Of Qur'an and Hadis Studies

Vol. 3 No. 1 (Juni 2020)

yang lebih banyak terpakai yaitu aniaya. Sebab perbuatan yang timbul tidak dari fikiran yang sehat adalah gelelapan dan adalah aniaya. Dengan ayat ini tegas-tegas Allah berfirman dengan perantara lidah Ibrahim disampaikan sebagai wahyu kepada Muhammad Saw bahwa beriman yang tidak dicampuri dengan zhulum yang berarti kegelapan berarti juga aniaya dan berarti juga syirik. Hanya beriman yang demikian lah yang akan mendapat keamanan dalam hati, baik keamanan perasaan di atas dunia maupun keamanan dari azab di akhirat dan mereka itulah yang mendapat hidayah dan petunjuk dari Allah, sehingga tercapailah kebennaran yang sejati dan sampai kepada apa yang dicita-citakan oleh tiap-tiap manusia yang mengenal tujuan hidup yaitu ridha Allah Swt.(Hamka, 2003, hlm. 2096-2097)

"Jikalau Sekiranya penduduk negeri-negeri beriman dan bertakwa, pastilah Kami akan melimpahkan kepada mereka berkah dari langit dan bumi, tetapi mereka mendustakan (ayat-ayat Kami) itu, Maka Kami siksa mereka disebabkan perbuatannya." (QS. Al-A'rāf 7: 96).(Kementerian Agama RI, 2015, hlm. 163)

Al-Maraghi menjelaskan akibat dari ketaatan kepada seruan Nabi Muhammad shalallahu 'alaihi wasallam untuk beribadah kepada Allah semata dan mereka mau meninggalkan segala yang dilarang, seperti syirik dan berbuat kerusakan di muka bumi dengan melakukan kekejian dan dosadosa, adalah Allah akan turunkan pada mereka hujan yang bermanfaat yang dapat menyuburkan tanah dan memberikan kemakmuran hidup dalam negeri serta Allah datangkan kepada mereka ilmu-ilmu, bermacam-macam pengetahuan dan kepahaman tentang sunah-sunah alam semesta yang belum pernah dicapai oleh umat manusia sebelumnya. Kesimpulannya bahwa andaikan mereka mau beriman niscaya Allah beri mereka kekayaan yang sangat luas dari segala penjuru, dan Allah mudahkan mereka mendapat ganti dari hukuman-hukuman yang telah menimpa mereka, sebagian dari langit dan ada pula dari bumi.(Al-Maraghi, 1993, hlm. 28)

Al-Maraghi dalam menentukan kesejahteraan seseorang tidaklah semata-mata menilai hanya dari materi saja karena dibukanya semua pintu kesenangan itu adalah sebagai cobaan dan ujian bagi mereka, yang akibatnya di antara mereka ada yang lupa daratan dan semakin jahat, bukannya bersyukur kepada pemberi nikmat. Sehingga kesenangan itu berubah menjadi bencana, bukan nikmat, dan menjadi fitnah bukan berkah. Lain halnya orang-orang yang beriman. Bagi mereka dibukakannya pintu-pintu kesenangan oleh Allah menjadikan mereka bersyukur kepada-Nya dan berterima kasih atas anugrah-Nya, lalu digunakan untuk hal-hal yang baik, bukan hal-hal yang buruk, dan untuk kepentingan pembangunan, bukan 
kerusakan. Oleh karenanya, mereka mendapat balasan berupa semakin bertambahnya kenikmatan di dunia dan pahala yang baik kelak di akhirat.(Al-Maraghi, 1993, hlm. 28)

Quraish Shihab menjelaskan dalam tafsirnya keimanan menjadikan seseorang selalu merasa aman dan optimis, dan ini mengantarkan hidup tenang dan dapat berkonsentrasi dalam usahanya, itu sebabnya keimanan kepada Allah selalu ditekankan dalam segala hal, termasuk dalam upaya memperoleh rizki. Sekian banyak ayat yang menyatakan bahwa Allah adalah penjamin rezeki: "Tidak ada satu binatang melatapun di dunia ini kecuali Allah yang menjamin rezeki-Nya" (QS. Hud: 6). Lebih jauh ditegaskan-Nya: "berapa banyak binatang yang tidak dapat mengurus rezekinya, Allah yang memberi rezeki juga kepadamu." (QS. Al-Ankabut: 60)

Menurut Buya Hamka Keimanan dan taqwa kepada Allah adalah kunci pembuka rezeki. Sebab kalau orang sudah beriman dan bertaqwa. fikirannya sendiri terbuka ilhampun datang sebab iman dan taqwa itu menimbulkan silaturrahmi sesama manusia. Lantaran itu timbullah kerja sama yang baik sebagai khalifah Allah di muka bumi. Dengan demikian turunlah berkat dari langit dan menyemburlah berkat dari bumi. Berkat itu dua macamnya yaitu yang hakiki dan yang ma'nawi.(Hamka, 2003, hlm. 2456) Yang hakiki ialah yang berupa hujan membawa kesuburan bumi, maka teraturlah tumbuhan dan keluarlah segala hasil bumi. Atau terbukalah fikiran manusia menggali harta dan kekayaan yang terpendam dalam bumi itu, seumpama besi, emas, perak logam dan yang lain, atau mengatur perkebunan yang luas menyuburkan ekonomi seumpama kopra, getah dan benang emas palm dan lain-lain. Yang ma'nawi ialah timbulnya fikiran-fikiran yang baru dan petunjuk dari Allah, baik berupa wahyu yang dibawakan oleh Rasul atau ilham yang ditumpahkan Allah kepada orang-orang yang berjuang dengan ikhlas dan dengan iman dan taqwa pusaka nenek moyang bias dipertahankan.(Hamka, 2003, hlm. 2456)

"Dan Allah telah berjanji kepada orang-orang yang beriman di antara kamu dan mengerjakan amal-amal yang saleh bahwa Dia sungguhsungguh akan menjadikan mereka berkuasa dimuka bumi, sebagaimana Dia telah menjadikan orang-orang sebelum mereka berkuasa, dan sungguh Dia akan meneguhkan bagi mereka agama yang telah diridhai-Nya untuk mereka, dan Dia benar-benar akan menukar (keadaan) mereka, sesudah mereka dalam ketakutan menjadi aman sentausa. mereka tetap menyembah-Ku dengan tiada mempersekutukan sesuatu apapun dengan Aku. dan Barangsiapa yang (tetap) kafir sesudah (janji) itu, Maka mereka Itulah orang- 
orang yang fasik." (QS. An-Nūr 24: 55)(Kementerian Agama RI, 2015, hlm. 357)

Al-Maraghi menjadikan kehidupan Rasul dan para sahabat sebagai contoh nyata pemenuhan janji Allah atas orang mu'min, Allah Ta`ala telah memenuhi janji-Nya, Rasulullah șalallahu 'alaihi wasallam tidak wafat hingga beliau menaklukkan kota Makkah, Khaibar, Bahrain dan seluruh wilayah Jazirah Arab, memungut upeti dari orang-orang Majusi Hajar dan sebagian penduduk Syam, serta menerima hadiah dari Haraclius. Raja Romawi, Maquqis di Mesir dan Najasyi Raja Habsyah. Setelah Rasulullah șalallahu 'alaihi wasallam wafat urusan dipegang oleh Al-Khulafa' Ar-Rashidin yang mengikuti jejak beliau. Mereka banyak menaklukkan wilayah Barat dan Timur, merobek-robek kerajaan para kisra (gelar raja Persia) menguasai kekayaan mereka dan memperbudak para pengikut kaisar (gelar raja Romawi).(Al-Maraghi, 1993, hlm. 229)

Qurai Shihab menjelaskan maksud mengerjakan amal-amal shaleh pada ayat ini tentu bukan semua amal saleh, tetapi sebagian besar dari amalamal saleh itu yang kadarnya cukup untuk menjadikan seseorang digelar sebagai orang saleh dan kumpulan dari mereka dinamai masyarakat yang saleh. Memang amal-amal saleh yang diamalkan oleh mayoritas anggota masyarakat akan memberi dampak bagi perkembangan positif masyarakat itu, menjadikan mereka kuat dan sejahtera lahir dan batin serta mengantar terjalinnya hubungan harmonis antar semua pihak sesuai dengan tuntunan agama.(Shihab, 2012, hlm. 186)

Buya Hamka menjelaskan bahwa Ayar 55 ini adalah inti tujuan perjuangan hidup dan inilah janji dan pengharapan yang telah dikemukakan Tuhan bagi setiap Mu'min dalam perjuangan menegakkan kebenaran dan keyakinan di permukaan bumi ini. Pokok pendirian seorang mu'min pertama ialah iman atau kepercayaan. kedua amal shaleh perbuatan baik, bukti dan bakti. Kalau iman tidak ada halauan perkerjaan tidaklah tentu arahnya entah berakibat baik ataukah berakibat buruk, iman sebagaimana yang telah barkali-kali diterangkan adalah pelita yang memberi cahaya dalam hati, bersinar cahaya itu keluar dan dapatlah petunjuk, sehingga nyatalah apa yang dikerjakan. Oleh sebab itu iman dengan sendirinya menimbulkan amal yang shaleh.(Hamka, 2003, hlm. 4963)

\section{Hakikat Kesejahteraan Masyarakat}

Hakikat kesejahteraan masyarakat yaitu seseorang/kelompok yang hidupnya tidak ada rasa takut dan tidak pula bersedih. Rasa takut ialah kegoncangan hati menyangkut sesuatu yang negatif di masa akan datang, 
sedangkan bersedih ialah kegelisahan menyangkut sesuatu yang negatif yang pernah terjadi. Untuk mencapai hal tersebut, Allah telah memerintahkan beberapa hal dalam QS al-An'am 82, al-A'raf 96 dan an-Nūr 55 sebagai berikut;

\section{Beriman dan tidak Dzalim}

Iman menurut batasan syara' ialah memadukan ucapan dengan pengakuan hati dan perilaku. Dengan lain perkataan mengikrarkan dengan lidah akan kebenaran Islam, membenarkan yang diikrarkan itu dengan hati dan tercermin dalam perilaku hidup sehari-hari dalam bentuk amal perbuatan. Iman dan aman sangat erat hubungannya, dimana kalau tidak ada iman dalam jiwa manusia, sukar akan tercapai keamanan dalam masyarakatnya. keamanan masyarakat berarti setiap orang memperoleh haknya, di samping kesanggupan memenuhi kewajibannya.(Fachruddin, 1992, hlm. 100)

\section{Mengerjakan Amal Saleh}

Menurut Quraish Shihab amal saleh adalah pekerjaan yang apabila dilakukan terhenti atau menjadi tiada (akibat pekerjaan tersebut) suatu mudharat (kerusakan) atau dengan dikerjakannya diperoleh manfaat dan kesesuaian.(Shihab, 2012, hlm. 588) Menurut Muhammad Abduh disebutkan bahwa amal saleh adalah segala perbuatan yang berguna bagi pribadi, kelompok, dan masyarakat secara keseluruhan.(Yusran, 2015, hlm. 127) Menurut Zamakhsyari adalah segala bentuk perbuatan yang sesuai dengan dalil akal, al-Qur'an dan as-Sunnah.(Yusran, 2015, hlm. 127)

Antara Iman dan amal saleh (perbuatan baik) dalam Al-Qur'an dijalin berpilin dengan eratnya, bagai tidak dapat atau tidak boleh diceraikan antara keduanya. berulangkali, apabila disebut alladzina amanu (orang-orang yang beriman) disambung dengan wa'amilushshalihat (dan mereka mengerjakan amal shaleh.)para ahli ilmu pernah memberikan perumpamaan amal saleh tanpa iman bagai pohon yang tiada mempunyai urat tunggang, sebaliknya iman yang tiada melahirkan amal soleh bagai pohon yang tiada berbuah.(Fachruddin, 1992, hlm. 95) dengan perkataan lain tiada menghasilkan apa-apa.

\section{Indikator Kesejahteraan Masyarakat}

Kesejahteraan merupakan sesuatu yang bersifat subjektif, sehingga ukuran kesejahteraan bagi setiap individu atau keluarga berbeda satu sama lain. Tetapi pada prinsipnya kesejahteraan berkaitan erat dengan kebutuhan dasar. Apabila kita lihat dalam Al-Qur'an indikator kesejahteraan dari masa ke masa hingga saat ini tidak mengalami perubahan. Al-Qur'an telah 
menyinggung indikator kesejahteraan dalam banyak surat di antaranya: Surat Quraisy ayat 3-4, "Maka hendaklah mereka menyembah Tuhan (pemilik) rumah ini (Ka'bah). yang telah memberikan makanan kepada mereka untuk menghilangkan lapar dan mengamankan mereka dari rasa takut"(Kementerian Agama RI, 2015, hlm. 602) berdasarkan ayat di atas, maka kita dapat melihat bahwa indikator kesejahteraan ada tiga, yaitu: (1) Menyembah Tuhan (pemilik) Ka'bah, (2) Menghilangkan lapar dan (3) Menghilangkan rasa takut.(Ismail, 2012, hlm. 390)

Dalam al-Qur'an, menurut Asep Usman Ismail, masyarakat yang sejahtera dinamakan al-muflihūn (المفلحون) yang secara harfiah berarti orangorang yang beruntung. Indikator masyarakat sejahtera (al-muflihūn),(Ismail, 2012, hlm. 390) yaitu "Mereka yang beriman kepada yang gaib, melaksanakan salat, dan menginfakkan sebagian rezeki yang Kami berikan kepada mereka, dan mereka beriman kepada (al-Qur'an) yang diturunkan kepadamu (Muhammad) dan (kitab-kitab) yang diturunkan sebelum engkau, dan mereka yakin adanya akhirat. Merekalah yang mendapat petunjuk dari Tuhannya, dan mereka itulah orang-orang yang beruntung (meraih kesejahteraan dunia dan akhirat) (QS al-Baqarah/2:4-5).(Kementerian Agama RI, 2015, hlm. 2)

Ayat lain yang menjadi rujukan bagi indikator kesejahteraan terdapat dalam Al-Qur'an surat An-Nisā' ayat 9 yang artinya adalah “Dan hendaklah takut kepada Allah orang-orang yang seandainya meninggalkan dibelakang mereka anak-anak yang lemah, yang mereka khawatir terhadap (kesejahteraan) mereka. oleh sebab itu hendaklah mereka bertakwa kepada Allah dan hendaklah mereka mengucapkan perkataan yang benar".(Kementerian Agama RI, 2015, hlm. 78) Berpijak pada ayat di atas, kita dapat menyimpulkan bahwa kekhawatiran terhadap generasi yang lemah adalah representasi dari kemiskinan, yang merupakan lawan dari kesejahteraan, ayat tersebut menganjurkan kepada manusia untuk menghindari kemiskinan dengan bekerja keras sebagai wujud ikhtiyar dan bertawakal kepada Allah,

Pada ayat di atas, Allah juga menganjurkan kepada manusia untuk memperhatikan generasi penerusnya (anak keturunannya) agar tidak terjatuh dalam kondisi kemiskinan, hal itu bisa dilakukan dengan mempersiapkan atau mendidik generasi penerusnya (anak keturunannya) dengan pendidikan yang berkualitas dan berorientasi pada kesejahteraan moral dan material, sehingga kelak menjadi SDM yang terampil dan berakhlakul karimah, mengingat anak adalah asset yang termahal bagi orang tua dan juga berbicara dengan jujur dan benar, serta Allah Swt. Juga menganjurkan untuk menyiapkan generasi penerus yang kuat, baik kuat 
dalam hal ketaqwaannya kepada Allah Swt. Maupun kuat dalam hal ekonomi,(Kementerian Agama RI, 2015, hlm. 391)

Al-Qur'an juga menyinggung tentang kesejahteraan yang terdapat pada surat An-Nahl ayat 97 "Barangsiapa yang mengerjakan amal saleh, baik laki-laki maupun perempuan dalam keadaan beriman, Maka Sesungguhnya akan kami berikan kepadanya kehidupan yang baik dan Sesungguhnya akan kami beri balasan kepada mereka dengan pahala yang lebih baik dari apa yang Telah mereka kerjakan".(Kementerian Agama RI, 2015, hlm. 278) yang dimaksud dengan kehidupan yang baik pada ayat di atas adalah memperoleh rizki yang halal dan baik, ada juga pendapat yang mengatakan kehidupan yang baik adalah beribadah kepada Allah disertai memakan dengan rizki yang halal dan memiliki sifat qana'ah, ada pendapat lain yang mengatakan kehidupan yang baik adalah hari demi hari selalu mendapat rizki dari Allah Swt. Menurut Al-Jurjani, rizki adalah segala yang diberikan oleh Allah Swt. Kepada hewan untuk diambil manfaatnya baik itu rizki halal maupun haram. (Ismail, 2012, hlm. 390-394)

Selanjutnya Ayat ke-20 dari Surat Al-hadid juga dijadikan sebagai rujukan bagi kesejahteraan masyarakat, yang artinya "Ketahuilah, bahwa Sesungguhnya kehidupan dunia Ini hanyalah permainan dan suatu yang melalaikan, perhiasan dan bermegah-megah antara kamu serta berbanggabanggaan tentang banyaknya harta dan anak, seperti hujan yang tanamtanamannya mengagumkan para petani; Kemudian tanaman itu menjadi kering dan kamu lihat warnanya kuning Kemudian menjadi hancur. dan di akhirat (nanti) ada azab yang keras dan ampunan dari Allah serta keridhaanNya. dan kehidupan dunia Ini tidak lain hanyalah kesenangan yang menipu".(Kementerian Agama RI, 2015, hlm. 540) Kita juga mengetahui bahwa berlomba-lomba dalam hal kemewahan duniawi dapat menjerumuskan manusia ke dalam kesombongan kebinasaan, seperti yang terdapat dalam Surat At-Takatsur ayat 1-2 yang artinya "Bermegah-megahan Telah melalaikan kamu. Sampai kamu masuk ke dalam kubur" (Ismail, 2012, hlm. 394)

Ayat di atas menjelaskan kepada kita bahwa aspek-aspek yang sering dijadikan indikator kesejahteraan seperti tingkat pendapatan (besarnya kekayaan), kepadatan penduduk (jumlah anak), perumahan, dan lain-lain bisa menipu seseorang jika tidak diiringi dengan pembangunan mental atau moral yang berorientasi pada nilai-nilai ketuhanan. yang pada gilirannya manusia dikhawatirkan akan terjebak pada persaingan kemewahan duniawi yang serba hedonis dan materialistik, dengan demikian 
penanaman tauhid (pembentukan moral dan mental) merupakan indikator utama bagi kesejahteraan.(Sodiq, 2015, hlm. 394)

\section{PENUTUP}

Hakikat kesejahteraan masyarakat ialah kondisi di mana terbebasnya suatu masyarakat dari jeratan kekufuran, kemiskinan, kebodohan, dan rasa takut sehingga dia memperoleh kehidupan yang aman dan tenteram secara lahiriah maupun batiniah. Gambaran ini dapat diperoleh dalam kehidupan di dunia dan juga di akhirat apabila setiap individu dapat menjaga keimanan mereka dan tidak mencampur adukkannya dengan kezaliman (baik itu syirik maupun pebuatan dosa lainnya) Sebagaimana dijelaskan dalam QS Al-An'am 82, al-A'raf 96 dan An-Nur 55 Dalam QS AlAn'am 82 ini di jelaskan bahwa seseorang yang tidak mencampurkan keimanan dengan kezaliman Allah janjikan keamanan di dunia dan di akhirat, Oleh karena itu, masyarakat diharapkan dapat menjaga dan memupuk keimanan mereka disebabkan masyarakat yang mentauhidkan Allah semata adalah masyarakat berkesejahteraan. Lalu keimanan itu direalisasikan dengan amal saleh, seperti dijelaskan pada pengertian iman, bahwa iman adalah dipercayai dengan hati, diucapkan dengan lisan lalu dibuktikan dengan amal perbuatan, Qurai Shihab menjelaskan dalam tafsirnya bahwa amal saleh yang disebutkan dalam QS an-Nur 55 bukanlah semua amal saleh tetapi hanya amal-amal yang dapat menjadikan seseorang disebut saleh.

Adapun indikator kesejahteraan masyarakat di dalam Al-Quran banyak terdapat dibanyak ayat yaitu meliputi kebutuhan materi dan non materi, dan yang paling utama di antara keduanya adalah non materi, pemantapan mental atau bisa juga dinamakan pemantapan iman dalam diri, merupakan pondasi awal yang harus dibentuk. jiwa yang tergantung kepada Allah akan dapat menarik kasih sayang Allah untuk melimpahkan segala yang diinginkannya, tapi jika hal itu belum terjadi dia tidak akan berputus asa karena dia tau bahwa Allah punya cara sendiri untuk membuatnya selalu merasa bahagia, dalam skripsi ini dijelaskan ada 4 indikator kesejahteraan di antaranya: beriman kepada Allah, memiliki harta (kekayaan), hidup seimbang dan berilmu dan bekerja.

\section{REFERENSI}

Al-Maraghi, A. M. (1993). Tafsir Al-Maraghi. Thoha Putra.

al-Sa'di, A. bin N. (2001). Taysir al-Karim al-Rahman. Makatabah al-Abikan.

Amelia, W. (2018). Kesejahteraan Sosial dalam Persfektif Al-Qur'an. UIN Alauddin Makassar. 
Journal Of Qur'an and Hadis Studies

Vol. 3 No. 1 (Juni 2020)

Dura, J. (2016). Pengaruh Akuntabilitas Pengelolaan Keuangan Alokasi Dana Desa, Kebijakan Dana Kelembagaan Desa terhadap Kesejahteraan Masyarakat. Jurnal Jibeka, 10(1).

Fachruddin. (1992). Ensiklopedi Al-Qur'an. Rineka Karya.

Hamka. (2003). Tafsir al-Azhar. Pustaka Nasional PTE LTD.

Hilmi, A. (2018). Konsep Hidup Sejahtera Perspektif Al-Qur'an (Studi Komparatif Penafsiran M. Quraish Shihab Dan Hamka). UIN Syarif Hidayatullah.

Ismail, A. U. (2012). Al-Qur'an dan Kesejahteraan Sosial: Sebuah Rintisan Pembangunan Paradigma Sosial Islam yang Berkeadilan dan Berkesejahteraan. Lentera Hati.

Jamil, M. (2011). Pergeseran Epistemologi dalam Tradisi Penafsiran AlQur'an. Jurnal Ilmiah Abdi Ilmu, 4.

Kaelany. (2000). Islam \& Aspek-Aspek Kemasyarakatan. Bumi Aksara.

Kementerian Agama RI. (2015). Al-Qur'an dan Terjemahnya. Al-Hadi Media Kreasi.

Muhdlor, A. A. a. Z. (1996). Kamus Kontemporer Arab Indonesia. Multi Karya Grafika.

Mustaniruddin, A. (2019). KONSEP AL-QUR'AN DALAM MEMBENTUK KESEJAHTERAAN SOSIAL MENUJU MASYARAKAT MADANI. At-Tibyan, 2(2), $35-53$.

Mustaqim, A. (2003). Madzahibut Tafsir. Nun Pustaka.

Mustaqim, A. (2009). Epistemologi Tafsir Kontemporer. LkiS.

Romziana, L. (2014). Pandangan Al-Qur\&\#39;an Tentang Makna Jâhilîyah Perspektif Semantik. Mutawâtir, 4(1), 117-138.

Sardar, Z., \& H.r, M. N. (2016). Kesejahteraan Dalam Perspektif Islam Pada Karyawan Bank Syariah. Jurnal Ekonomi Syariah Teori Dan Terapan, 3(5), 391. https://doi.org/10.20473/vol3iss20165pp391

Shihab, M. Q. (2012). Tafsir Al-Mishbah: Pesan, Kesan, dan Keserasian AlQur'an. Lentera Hati.

Sodiq, A. (2015). Konsep Kesejahteraan Dalam Islam. Jurnal STAIN Kudus Equilibrium, 3.

Soekanto, S. (1993). Kamus Sosiologi. Citra Niaga Rajawali Pers. 


\section{AT-TIBYAN}

Journal Of Qur'an and Hadis Studies

Vol. 3 No. 1 (Juni 2020)

Sugono, D. (2003). Kamus Pelajar Sekolah Lanjutan Tingkat Pertama. Pusat Bahasa Departemen Pendidikan Nasional.

Sunarto, A. (2002). Kamus Lengkap Al-Fikr. Halim Jaya.

Yusran. (2015). Amal Saleh: Doktrin Teologi dan sikap sosial. Jurnal al-Adyan, $1(2)$. 